\title{
Applications of nanofluids in geothermal: A review
}

\author{
Mohammad Hossein Ahmadi ${ }^{*}$, Mahdi Ramezanizadeh², Mohammad Alhuyi Nazari ${ }^{2}$, Giulio Lorenzini ${ }^{3}$, Ravinder Kumar ${ }^{4}$ \\ Ravindra Jilte ${ }^{4}$ \\ ${ }^{1}$ Faculty of Mechanical of engineering, Shahrood University of Technology, Shahrood, Iran \\ ${ }^{2}$ Aerospace Engineering Department, Shahid Sattari Aeronautical University of Science and Technology, Tehran, Iran \\ ${ }^{3}$ Università degli Studi di Parma, Dipartimento di Ingegneria e Architettura, Parma 43124, Italy \\ ${ }^{4}$ Department of Mechanical Engineering, Lovely Professional University, Phagwara-144411 Punjab, India
}

Corresponding Authors Email: mohammadhosein.ahmadi@gmail.com

https://doi.org/10.18280/mmep.050402

Received: 20 July 2018

Accepted: 29 September 2018

\section{Keywords:}

nanofluid, geothermal, heat transfer, renewable energy

\begin{abstract}
Geothermal energy is one of the most suitable sources of energy since it is possible to use it continuously for generating power and providing heat. Firstly, recent trends in geothermal energy are discussed and compared with other types of renewable energies. According to the results of this section, geothermal energy is an attractive choice for future power generation due to its low carbon dioxide emission and levelzied cost of electricity in comparison with other renewable energy sources. Afterwards, applications of nanofluid in geothermal-based energy systems are reviewed and their important results are represented. On the basis of literature review, using nanofluids can result in augment in geothermal systems. The enhancement is dependent on several factors including the type of nanofluid, concentration and system specification. According to the results of a study, the effect of using nanofluid on heat transfer rate became more significant at higher flow rates. In addition, using nanofluids can reduce the size of heat exchangers used in geothermal-based system. The main effects of employing nanofluids is increase in convective heat transfer and pressure loss.
\end{abstract}

\section{INTRODUCTION}

$\mathrm{T}$ The primary energy supply of the world has increasing trend because of industrial development and population growth [1-2]. Total primary energy supply increased by approximately 2.5 times between 1971 and 2016 [3]. Another important aspect which must be considered in energy sector is environmental issues [4-5]. Based on International Energy Agency report, energy related carbon dioxide emission had $1.4 \%$ growth in 2017. Clean energy sources including solar, geothermal, wind and hydropower gained importance in recent decades because of fossil fuels' environmental problems and the possibility of their exhaustion in near future [6-7]. Renewable energies are employed for various applications such as heating [8-10], cooling [11], electricity generation [12-13], and desalination [14]. According to International Energy (IEA) report [15], the share of renewable energies in various sectors will increase as shown in Figure 1. As it is illustrated, it is expected to have increase in global renewable energy demand.

Geothermal energy is one of the most attractive renewable sources due to its low environmental issues and affordable cost of generated electricity and provided heat by using this source of energy [17]. Since the stored thermal energy must be extracted for using geothermal, heat transfer augment has significant importance. By improving the heat transfer, the overall efficiency of the system can be improved. Studies have shown that nanofluids are appropriate choices for improving heat transfer [18-20]. Nanofluids are applicable in numerous heat transfer mediums such as heat pipes, heat exchangers and etc. [21-24].

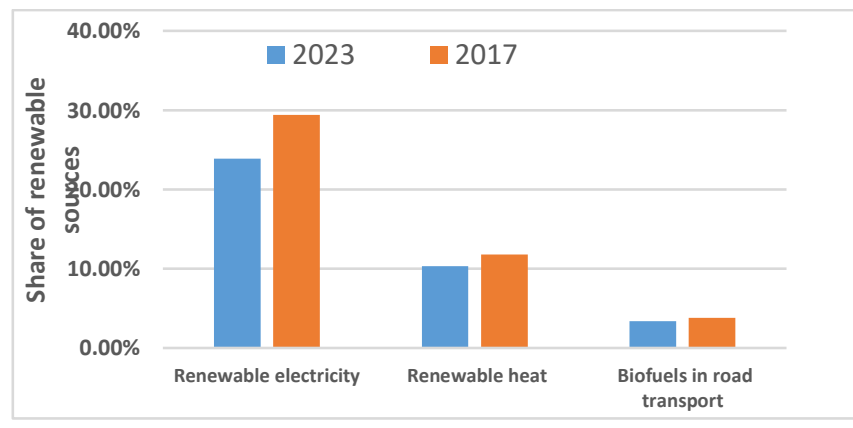

Figure 1. Future of renewable energy sources in various sectors [16]

Heat transfer enhancement by employing nanofluids is mainly attributed to its higher thermal conductivity in comparison with conventional fluids [25-27]. Increase in the thermal conductivity of these fluids is due to dispersion of solid nanostructures which have higher thermal conductivity compared with liquids [28]. Various materials such as metaloxide, metal and carbonic structures can be used as nanostructures to prepare nanofluids [29-32]. The properties of nanofluids are highly dependent on the type of solid phase, synthesis procedure, temperature and other factors [33-35]. Nanofluids are broadly utilized in various renewable energy systems such as PV/T, solar collectors and solar ponds [3637]. The results of studies have revealed that applying 
nanofluids in the mentioned renewable energy systems results in improved performance and efficiency.

In addition to solar energy applications of nanofluids, these types of fluids are applicable in geothermal-based energy systems [38]. Due to their improved thermal specifications, it is expected to achieve higher efficiency by using nanofluids. In this study, applications of nanofluids in geothermal energy systems are reviewed. The important findings of the reviewed studies are represented and discussed. Finally, some suggestions are offered for future researches based on the results of the literature review.

\section{GEOTHERMAL ENERGY OVERVIEW}

$\mathrm{T}$ Geothermal energy exists in rock and trapped liquid or vapor which can be applied for heating and generating electricity [39-40]. Generally, geothermal resources with temperature higher than $100{ }^{\circ} \mathrm{C}$ are required for electricity generation; while there is a wide range for temperatures appropriate for heating [39]. Electricity generation by using geothermal energy have some advantages compared with fossil fuels plant, solar PV modules and hydropower, since it has lower carbon dioxide emission. Comparison between life cycle emission of various energy resources for electricity generation is represented in Figure 2. In addition to lower carbon dioxide emission, it is possible to generate electricity with lower levelized cost compared with other renewable resources as shown in Figure 3.

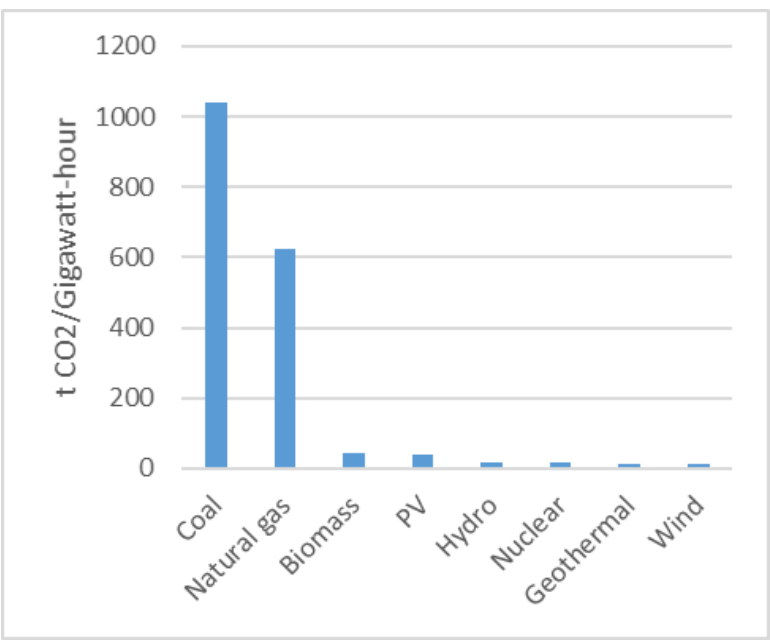

Figure 2. $\mathrm{CO}_{2}$ emission of various energy resources for electricity generation [41]

Geothermal energy is more continuous compared with solar and wind which are intermittent. Due to this fact, electricity generation by using this renewable energy source is more reliable. According to the mentioned advantages, installation of geothermal-based power plants had growing trends in recent years. As shown in Figure 4, the cumulative capacity of geothermal power plants in the world has increased from $10.34 \mathrm{GW}$ in 2007 to 14.30 in 2017. Among various countries, US has the highest share of installed geothermal power plants with $26.0 \%$. Philippines and Indonesia had the 2nd and 3rd ranks with $13.5 \%$ and $13 \%$, respectively [43]. It is expected to reach $1400 \mathrm{TWh}$ electricity generation per year by using geothermal sources by 2050 , which means $3.5 \%$ of global generated electricity
[44]. In addition to electricity generation, geothermal heat has ability to contribute $3.9 \%$ of final energy for heat by 2050, which means 1600 TWh thermal energy [44].

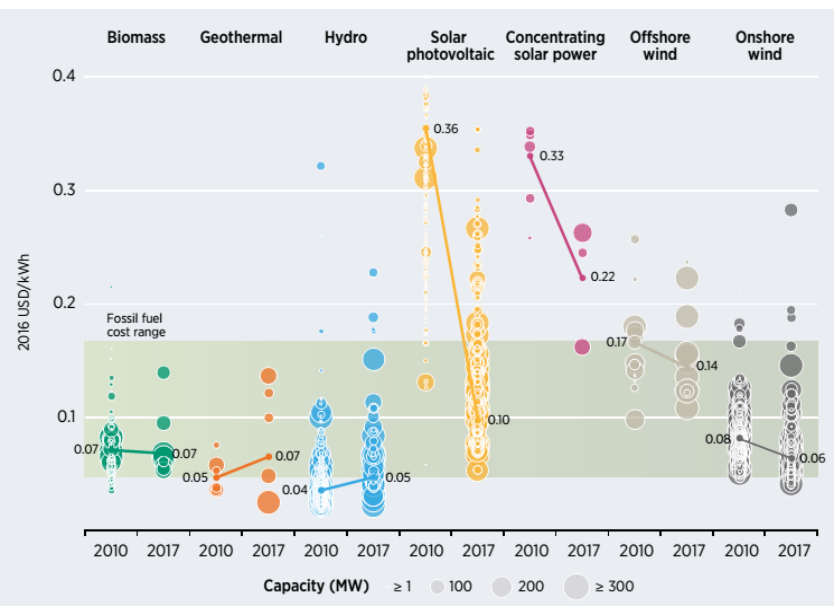

Figure 3. Global levelized cost of electricity for utility scale (CIRENA 2018) [42]

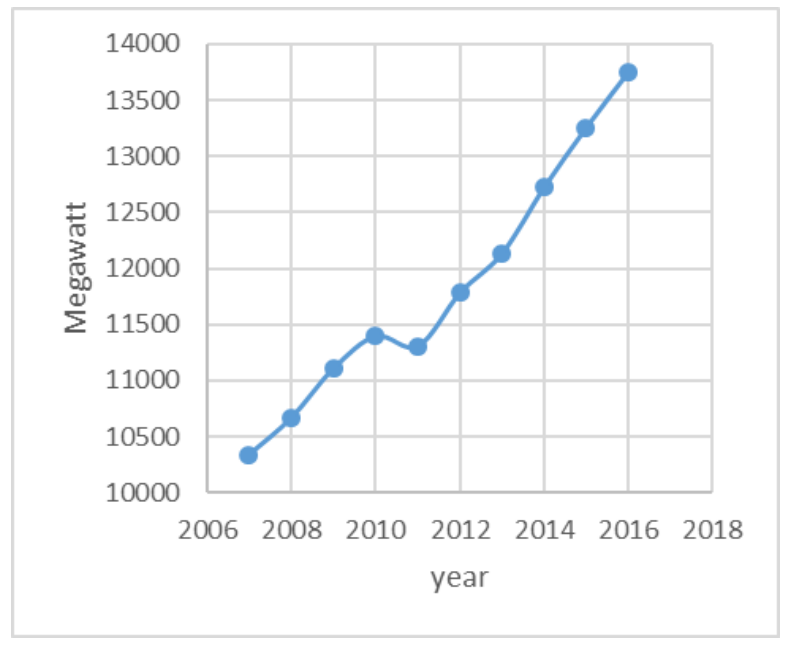

Figure 4. Cumulative installed geothermal power plants [43]

As it is discussed, geothermal sources have high potential for electricity generation and providing required heat for various purposes. Due to this fact, it is necessary to find ways and approaches for enhancement in geothermal-based energy systems. There are some researches focused on using nanofluids in these systems which are reviewed in following section.

\section{APPLICATIONS OF NANOFLUIDS IN GEOTHERMAL SYSTEMS}

Heat transfer processes play key role in the efficiency of geothermal energy systems [45]. Enhancement in thermal performance of thermal devices applied in these systems leads to improved efficiency of the overall system. Applying nanofluids as heat transfer fluids is an attractive idea to achieve higher efficiencies [46]. In addition to improvement in heat transfer, using nanofluids can reduce the size of systems. Diglio et al. [47] investigated the effect of using nanofluid as heat carrier instead of conventional fluid, mixture of water and ethylene glycol, on a borehole heat exchanger. In this study, various nano particles such as 
graphite, alumina, aluminium and etc were used in low concentrations. The volumetric concentrations of nanofluids were between $0.1 \%$ and $1 \%$. It was observed that applying nanofluids can result in reduction in borehole thermal resistance. Since the type of nano structures influences on the thermophysical specifications [48], the results were dependent on the kind of nanofluids as shown in Figure 5. In addition, it was observed that using $\mathrm{Ag}$ nanofluids resulted in the highest convective heat transfer and pressure drop. By considering both heat transfer and pressure drop, it was concluded that using $\mathrm{Cu}$-based nanofluids led to the most reduction in the length of borehole heat exchanger.

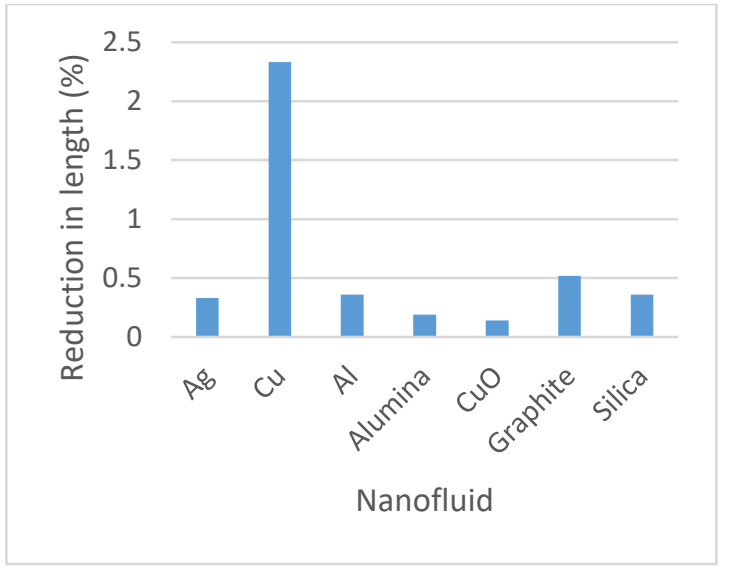

Figure 5. Borehole length reduction for various nanofluids in $1 \%$ concentration [47]

In another study carried out by Deneshipour et al. [49], two nanofluids including $\mathrm{Al}_{2} \mathrm{O}_{3} /$ water and $\mathrm{CuO} /$ water were used in geothermal borehole heat exchanger as circuit fluids. Numerical simulation by applying Reynolds Averaged Navier-Stokes was performed to analyze the effect of various factors. The turbulence model employed in the research was SST k- $\omega$. The volumetric concentration varied between $0 \%$ and $6 \%$ to evaluate the impact of concentration. Results of the study revealed that by using $\mathrm{CuO} /$ water nanofluid, higher heat extraction was achievable compared with $\mathrm{Al}_{2} \mathrm{O}_{3}$ /water nanofluid; however, the pressure loss was higher in the case of using $\mathrm{CuO} /$ water nanofluid. Moreover, the results indicated higher local convective heat transfer coefficient by increment in the concentration of the nanofluids. Jamshidi et al. [50] numerically investigated the performance of geothermal heat exchanger and the effects of utilizing nanofluids in extracted heat. In their study, $\mathrm{Al}_{2} \mathrm{O}_{3}$ nano particles were employed in volumetric concentrations between 0 and $0.5 \%$. The obtained results showed that increase in the concentration resulted in improved heat flux. Moreover, the influence of size of nano particles on heat transfer was evaluated. The utilized heat exchanger in this study was finned conical helical type. It was concluded that using nano particles with lower dimensions resulted in improvement in Brownian motion; consequently, the heat transfer rate increased. According to the results of the research, employing the nano particles in $0.5 \%$ vol concentration could lead to approximately $18 \%$ increase in obtained energy from the earth.

The extracted heat from the earth in geothermal systems depends on numerous factors such as working fluid, its flow rate and well specification. In a study carried out by Sui et al. [51], $\mathrm{Al}_{2} \mathrm{O}_{3}$ /water nanofluid was employed as working fluid in a geothermal system. The thermophysical properties of the applied nanofluids, such as specific heat, dynamic viscosity and thermal conductivity, were calculated on the basis of the models proposed for them. In the first step, the effect of mass flow rate was investigated. The results showed that increase in flow rate led to lower temperature of returning flow and increment in extracted heat. In addition, the effect of adding nano particles to the working fluid was studied. According to the results, using nanofluid resulted in increased temperature of returning fluid. At low mass flow rate, the effect of using nanofluid on extracted heat was not significant, while increase in mass flow rate made it more sensible. For instance, in the case of $15 \mathrm{~kg} / \mathrm{m}^{3}$, the extracted heat by using water and nanofluid were $3050 \mathrm{~kW}$ and $3393 \mathrm{~kW}$, respectively.

Although using nanofluids in heat exchangers of geothermal systems can improve the heat transfer and efficiency, there are some concerns about them. Sedimentation of nano particles can deteriorate heat transfer and performance of the systems. There are some suggestions to overcome these probable problems. According to a study conducted by Sun et al. [52], in the case of static fluid in shut-down condition, accumulation of nano particles appeared to exist close the bottom of borehole after long time (many hours) sedimentation. A numerical simulation was carried out to evaluate this phenomenon. Based on the results, relatively high velocity of the fluid can remove the accumulated particles which results in reliable performance of nanofluidic heat exchangers in geothermal systems.

\section{CONCLUSION}

In the present article, a review study is carried out on the geothermal systems use nanofluids. In the first step, an overview of geothermal energy systems is provided. According to the literature review, geothermal energy is an appropriate alternative for fossil fuel power plants. Greenhouse gas emission of geothermal energy in generating electricity is much lower compared with fossil fuels. Moreover, the levelized cost of electricity generated by geothermal energy sources is very low which makes it more attractive for power production. In the next stage, the applications of nanofluids in geothermal energy systems are reviewed. According to the results, nanofluids are generally applied as heat transfer fluid in heat exchangers due to their ability in thermal enhancement. Using nanofluids in heat exchangers and boreholes can reduce the size of structures and improve the efficiency of the systems. The recommendation for future studies is focusing of finding various types of nanofluids, specially carbonic nano structures, to find more desirable fluids for heat transfer. Moreover, nanotechnology can be applied in geothermal structures due to their ability in enhancing the mechanical properties and heat transfer capacity.

\section{REFERENCES}

[1] Madlool NA, Saidur R, Hossain MS, Rahim NA. (2011). A critical review on energy use and savings in the cement industries. Renew Sustain Energy Rev 15: 2042-60. https://doi.org/10.1016/J.RSER.2011.01.005 
[2] Amin TE, Roghayeh G, Fatemeh R, Fatollah P. (2015). Evaluation of nanoparticle shape effect on a nanofluid based flat-plate solar collector efficiency. Energy Explor Exploit 33: 659-76 https://doi.org/10.1260/0144-5987.33.5.659

[3] https://www.iea.org/statistics/balances/ n.d.

[4] Barzegar Avval H, Ahmadi P, Ghaffarizadeh AR, Saidi MH. (2011). Thermo economic environmental multiobjective optimization of a gas turbine power plant with preheater using evolutionary algorithm. Int $\mathrm{J}$ Energy Res 35: 389-403. https://doi.org/10.1002/er.1696

[5] Ahmadi MH, Ghazvini M, Sadeghzadeh M, Alhuyi Nazari M, Kumar R, Naeimi A. (2018). Solar power technology for electricity generation: A critical review. Energy Sci Eng. https://doi.org/10.1002/ese3.239

[6] Ahmadi MH, Ahmadi MA, Sadaghiani MS, Ghazvini M, Shahriar S, Alhuyi Nazari M. (2018). Ground source heat pump carbon emissions and ground-source heat pump systems for heating and cooling of buildings: A review. Environ Prog Sustain Energy 37. https://doi.org/10.1002/ep.12802

[7] Rezaei MH, Sadeghzadeh M, Alhuyi Nazari M, Ahmadi MH, Astaraei FR. (2018). Applying GMDH artificial neural network in modeling $\mathrm{CO}_{2}$ emissions in four nordic countries. Int $\mathrm{J}$ Low-Carbon Technol. https://doi.org/10.1093/ijlct/cty026

[8] Haghighi Bardineh Y, Mohamadian F, Ahmadi MH, Akbarianrad N. (2018). Medical and dental applications of renewable energy systems. Int $\mathrm{J}$ Low-Carbon Technol. https://doi.org/10.1093/ijlct/cty040

[9] [9] Alhuyi Nazari M, Ahmadi MH, Ghasempour R, Shafii MB, Mahian O, Kalogirou S, et al. (2018). A review on pulsating heat pipes: From solar to cryogenic applications. Appl Energy 222: 475-84 https://doi.org/10.1016/j.apenergy.2018.04.020

[10] Benhouia AT, Teggar M, Benchatti A. (2018). Effect of sand as thermal damper integrated in flat plate water solar thermal collector. Int J Heat Technol 36: 21-5. https://doi.org/10.18280/ijht.360103

[11] Cascetta F, Cirillo L, Della Corte A, Nardini S. (2017). Comparison between different solar cooling thermally driven system solutions for an office building in Mediterranean Area. Int J Heat Technol 35: 130-8. https://doi.org/10.18280/ijht.350118

[12] Alhuyi Nazari M, Aslani A, Ghasempour R. (2018). Analysis of solar farm site selection based on TOPSIS approach. Int J Soc Ecol Sustain Dev 9.

[13] Alizadeh H, Ghasempour R, Shafii MB, Ahmadi MH, Yan WM, Nazari MA. (2018). Numerical simulation of PV cooling by using single turn pulsating heat pipe. Int J Heat Mass Transf 127: 203-8 https://doi.org/10.1016/J.IJHEATMASSTRANSFER.20 18.06.108

[14] Faegh M, Shafii MB. (2017). Experimental investigation of a solar still equipped with an external heat storage system using phase change materials and heat pipes. Desalination 409: 128-35. https://doi.org/10.1016/j.desal.2017.01.023

[15] No Title n.d. https://www.iea.org/topics/renewables/.

[16] IEA - Report n.d. http://www.iea.org/statistics (accessed April 15, 2018).

[17] Arslan U, Huber H. (2013). Characterization of heat transport processes in geothermal systems. Int J Low- $\begin{array}{llll}\text { Carbon } & \text { Technol } & \text { 8: } & \text { 71-9. }\end{array}$

https://doi.org/10.1093/ijlct/ctt014

[18] Alhuyi Nazari M, Ahmadi MH, Ghasempour R, Shafii MB. (2018). How to improve the thermal performance of pulsating heat pipes: A review on working fluid. Renew Sustain Energy Rev 91. https://doi.org/10.1016/j.rser.2018.04.042

[19] Mohammadi M, Taslimifar M, Haghayegh S, Hannani SK, Shafii MB, Saidi MH, et al. (2014). Open-loop pulsating heat pipes charged with magnetic nanofluids: Powerful candidates for future electronic coolers. Nanoscale Microscale Thermophys Eng 18: 18-38. https://doi.org/10.1080/15567265.2013.787570

[20] Maddah H, Alizadeh M, Ghasemi N, Wan Alwi SR. (2014). Experimental study of $\mathrm{Al}_{2} \mathrm{O}_{3}$ /water nanofluid turbulent heat transfer enhancement in the horizontal double pipes fitted with modified twisted tapes. Int $\mathbf{J}$ Heat Mass Transf 78: 1042-54. https://doi.org/10.1016/j.ijheatmasstransfer.2014.07.059

[21] Nazari MA, Ghasempour R, Ahmadi MH, Heydarian G, Shafii MB. (2018). Experimental investigation of graphene oxide nanofluid on heat transfer enhancement of pulsating heat pipe. Int Commun Heat Mass Transf 91:

$90-4$. https://doi.org/10.1016/j.icheatmasstransfer.2017.12.00 6

[22] Gandomkar A, Saidi MH, Shafii MB, Vandadi M, Kalan K. (2017). Visualization and comparative investigations of pulsating ferro-fluid heat pipe. Appl Therm Eng 116: 56-65. https://doi.org/10.1016/J.APPLTHERMALENG.2017.0 1.068

[23] Maddah H, Ghasemi N, Keyvani B, Cheraghali R. (2017). Experimental and numerical study of nanofluid in heat exchanger fitted by modified twisted tape: exergy analysis and ANN prediction model. Heat Mass Transf Und Stoffuebertragung 53: 1413-23. https://doi.org/10.1007/s00231-016-1906-2

[24] Xin-hua W, Yu-lin J, Yong-chao NIU, Jie Y. (2015). Study on enhanced heat transfer features of nanomagnetic fluid heat pipe under magnetic field. Int $\mathrm{J}$ Heat Technol 33: 137-44. https://doi.org/10.18280/ijht.330119

[25] Ahmadi MH, Ahmadi MA, Nazari MA, Mahian O, Ghasempour R. (2018). A proposed model to predict thermal conductivity ratio of $\mathrm{Al}_{2} \mathrm{O}_{3} / \mathrm{EG}$ nanofluid by applying least squares support vector machine (LSSVM) and genetic algorithm as a connectionist approach. J Therm Anal Calorim 1-11. https://doi.org/10.1007/s10973-018-7035-z

[26] RamReddy C, Murthy PVSN, Chamkha AJ, Rashad AM. (2013). Soret effect on mixed convection flow in a nanofluid under convective boundary condition. Int $\mathbf{J}$ Heat Mass Transf 64: 384-92. https://doi.org/10.1016/J.IJHEATMASSTRANSFER.20 13.04 .032

[27] Mashaei PR, Shahryari M, Madani S. (2016). Numerical hydrothermal analysis of water- $\mathrm{Al}_{2} \mathrm{O}_{3}$ nanofluid forced convection in a narrow annulus filled by porous medium considering variable properties. J Therm Anal Calorim 126: 891-904. https://doi.org/10.1007/s10973-016-5550-3

[28] Sivakumar A, Alagumurthi N, Senthilvelan T. (2015). Experimental and numerical investigation of forced 
convective heat transfer coefficient in nanofluids of $\mathrm{Al}_{2} \mathrm{O}_{3} /$ water and $\mathrm{CuO} / \mathrm{EG}$ in a serpentine shaped microchannel heat sink. Int J Heat Technol 33: 155-60. https://doi.org/10.1007/s00231-015-1649-5

[29] Akbarianrad N, Mohammadian F, Alhuyi Nazari M, Rahbani Nobar B. (2018). Applications of nanotechnology in endodontic: A review. Nanomedicine $\quad$ J 5 : $121-6$ https://doi.org/10.22038/NMJ.2018.005.0001

[30] Ahmadi MA, Ahmadi MH, Fahim Alavi M, Nazemzadegan MR, Ghasempour R, Shamshirband S. (2018). Determination of thermal conductivity ratio of $\mathrm{CuO} /$ ethylene glycol nanofluid by connectionist approach. J Taiwan Inst Chem Eng. https://doi.org/10.1016/J.JTICE.2018.06.003

[31] Hemmat Esfe M, Wongwises S, Rejvani M. (2017). Prediction of thermal conductivity of carbon nanotubeeg nanofluid using experimental data by ANN. Curr Nanosci 13: 324-9.

[32] Esfe MH, Esfandeh S, Afrand M, Rejvani M, Rostamian SH. (2018). Experimental evaluation, new correlation proposing and ANN modeling of thermal properties of EG based hybrid nanofluid containing ZnO-DWCNT nanoparticles for internal combustion engines applications. Appl Therm Eng 133: 452-63. https://doi.org/10.1016/J.APPLTHERMALENG.2017.1 1.131

[33] Ahmadi MH, Mirlohi A, Alhuyi Nazari M, Ghasempour R. (2018). A review of thermal conductivity of various nanofluids. J Mol Liq 265: 181-8. https://doi.org/10.1016/J.MOLLIQ.2018.05.124

[34] Leong KY, Ku Ahmad KZ, Ong HC, Ghazali MJ, Baharum A. (2017). Synthesis and thermal conductivity characteristic of hybrid nanofluids - A review. Renew Sustain Energy Rev 75: 868-78. https://doi.org/10.1016/J.RSER.2016.11.068

[35] Ghanbarpour M, Bitaraf Haghigi E, Khodabandeh R. (2014). Thermal properties and rheological behavior of water based $\mathrm{Al}_{2} \mathrm{O}_{3}$ nanofluid as a heat transfer fluid. Exp Therm Fluid Sci 53: 227-35. https://doi.org/10.1016/J.EXPTHERMFLUSCI.2013.12 .013

[36] Aramesh M, Pourfayaz F, Kasaeian A. (2017). Numerical investigation of the nanofluid effects on the heat extraction process of solar ponds in the transient step. Sol Energy 157: 869-79. https://doi.org/10.1016/J.SOLENER.2017.09.011

[37] Ghaderian J, Sidik NAC, Kasaeian A, Ghaderian S, Okhovat A, Pakzadeh A. (2017). Performance of copper oxide/distilled water nanofluid in evacuated tube solar collector (ETSC) water heater with internal coil under thermosyphon system circulations. Appl Therm Eng 121: $520-36$ https://doi.org/10.1016/j.applthermaleng.2017.04.117.
[38] Faizal M, Bouazza A, Singh RM. (2016) Heat transfer enhancement of geothermal energy piles. Renew Sustain Energy Rev 57: 16-33.

[39] Heat G. (2011). Geothermal roadmap - geothermal heat and power. Paris: International Energy Agency.

[40] Preißinger M, Heberle F, Brüggemann D. (2013). Advanced organic rankine cycle for geothermal application. Int $\mathrm{J}$ Low-Carbon Technol 8: i62-8. https://doi.org/10.1093/ijlct/ctt021

[41] Ezzat MF. (2018). Geothermal Energy Production.Compr Energy Syst 252-303. https://doi.org/10.1016/B978-0-12-809597-3.00313-8

[42] Renewable power generation costs in 2017. IRENA 2018.

[43] BP Statistical Review of World Energy. 2018.

[44] Technology Roadmap Geothermal Heat and Power. International Energy Agency. 2011.

[45] Wang K, Yuan B, Ji G, Wu X. (2018). A comprehensive review of geothermal energy extraction and utilization in oilfields. J Pet Sci Eng 168: 465-77. https://doi.org/10.1016/J.PETROL.2018.05.012

[46] Bobbo S, Colla L, Barizza A, Rossi S, Fedele L, Nazionale C. (2016). Characterization of nanofluids formed by fumed $\mathrm{Al}_{2} \mathrm{O}_{3}$ in water for geothermal applications. Int Compress Eng Refrig Air Cond High Perform Build Conf 1-9.

[47] Diglio G, Roselli C, Sasso M, Jawali Channabasappa U. (2018). Borehole heat exchanger with nanofluids as heat carrier. Geothermics 72: 112-23. https://doi.org/10.1016/J.GEOTHERMICS.2017.11.005

[48] Ahmadi MH, Hajizadeh F, Rahimzadeh M, Shafii MB, Chamkha AJ. (2018). Application GMDH artificial neural network for modeling of $\mathrm{Al}_{2} \mathrm{O}_{3} /$ water and $\mathrm{Al}_{2} \mathrm{O}_{3}$ / Ethylene glycol thermal conductivity 36: 773-82.

[49] Daneshipour M, Rafee R. (2017). Nanofluids as the circuit fluids of the geothermal borehole heat exchangers. Int Commun Heat Mass Transf 81: 34-41. https://doi.org/10.1016/J.ICHEATMASSTRANSFER.2 016.12 .002

[50] Jamshidi N, Mosaffa A. (2018). Investigating the effects of geometric parameters on finned conical helical geothermal heat exchanger and its energy extraction capability. Geothermics 76: 177-89. https://doi.org/10.1016/J.GEOTHERMICS.2018.07.007

[51] Sui D, Langåker VH, Yu Z. (2017). Investigation of thermophysical properties of nanofluids for application in geothermal energy. Energy Procedia 105: 5055-60. https://doi.org/10.1016/J.EGYPRO.2017.03.1021

[52] Sun XH, Yan H, Massoudi M, Chen ZH, Wu WT, Sun XH. (2018). Numerical simulation of nanofluid suspensions in a geothermal heat exchanger. Energies 11: 919. https://doi.org/10.3390/en11040919 